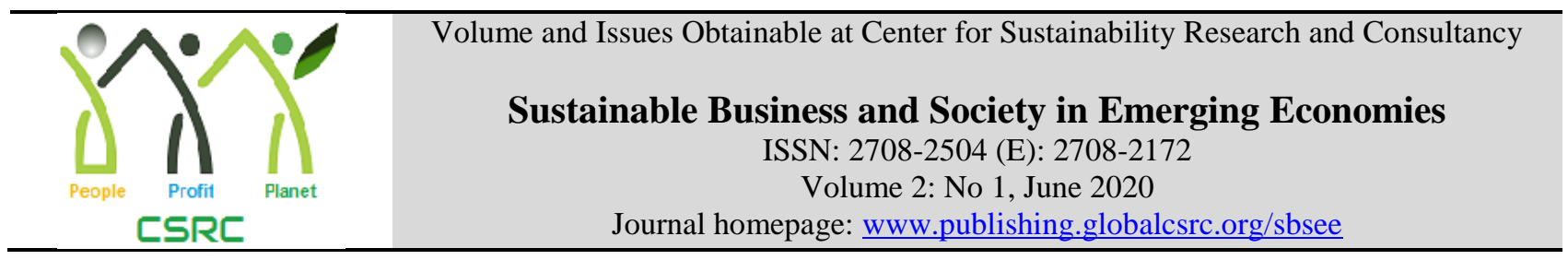

\title{
The Game Changer': A Critical Discourse Analysis of News Headlines about CPEC
}

\section{${ }^{1}$ Rehana Yasmin Anjum, ${ }^{2}$ Faiza Manzoor}

${ }^{1}$ PhD Scholar, University of Management and Technology, Lahore Pakistan, Rehana786@ yahoo.com

${ }^{2}$ Lecturer, University of Management and Technology, Sialkot Pakistan, faiza.manzoor@skt.umt.edu.pk

\begin{tabular}{l} 
ARTICLE DETAILS \\
\hline History \\
Revised format: May 2020 \\
Available Online: June 2020
\end{tabular}

Keywords

Van Dijk Modal, discursive

Practices, CPEC

\section{JEL Classification:}

M2, $M 12$

\begin{abstract}
CPEC has become the centre of attention for the whole world as it has been entitled as "a game changer", since Chine has been connected to the European and Gulf states through CPEC via Silk Road. Gawadar has become an important trade centre of the future. Due to the said key reasons, this issue is being manipulated and portrayed in different colours at national and international forums. Keeping the present scenario in view, the present study has been invested to explore the hidden strategies of different local news papers that how this phenomenon is being portrayed and manipulated. It is an analytical research of media discourse that primarily studies how social power and inequality is manipulated and reproduced through text and talk in both social and political contexts.CDA of journalistic discourse tries to unveil the biased language to make the readers aware of manipulative strategies used in both printed and online news papers. The present study aims at making a comparative study of three daily English newspapers, The "Dawn News", "The Express Tribune" and "The Business Recorder" about the news headlines on CPEC (China-Pakistan Economic Corridor) to show the negotiation on the important issues like CPEC via news headlines. Through investing the Critical Discourse Analysis as method the researchers have tried to investigate the manipulations invested by the editors to represent their own ideologies on the same issue. To meet the same goal three headlines were collected from all these three news papers dealing with the same phenomenon. All those headlines were analysed on the modal of Van Dijk (2000) in terms of discursive strategies through discursive micro and macro strategies presented by Van Dijk. The nature of the study is qualitative. The results show a controversial approach towards the acceptance of this mega project and apprehensions of the stake holders and political figures.
\end{abstract}

(C) 2020 The authors, under a Creative Commons Attribution-NonCommercial

4.0

Corresponding author's email address: faiza.manzoor@ skt.umt.edu.pk

Recommended citation: Anjum, R. Y., \& Manzoor, F. (2020). The Game Changer': A Critical Discourse Analysis of News Headlines about CPEC. Sustainable Business and Society in Emerging Economies, 2(1), 73-81 


\section{Introduction}

We live in the age of information technology where the world has been turned into a global village due to fast communicative systems and rapid connections. Now every social, political, economic, and strategic and even a personal event rapidly become public and globalized through different sources of media and other modes of communication. In a real sense media is responsible for playing a leading and eminent part in changing an ordinary event into a great interest of the public and the whole world.

Media is such a powerful tool that can manipulate the events according to its own interests and the demands of the time and situation. Especially when strategic and vested geopolitical interests of a nation become a central concern at global level then the very thoughts, view points and concerns can be viewed and analysed through the news headlines about the certain phenomenon round the world. We can observe that how things are being manipulated and presented on media to give a certain impression according to strategic, social, political and national interests.

CPEC has become the centre of attention for the whole world as it has been entitled as "a game changer"(online sources The Dawn, The Nation, BBC News, The Hindu, The Gulf News 2016, 2016, 2015, 2016, 2017) since Chine has been connected to the European and Gulf states through CPEC. Gawadar has become an important trade centre of the future. Due to these key reasons, this issue is being manipulated and portrayed in different colours at national and international forums.

According to Van Dijk's model (1988) the primary objective of media is to discuss carefully and analyse the language used in a discourse to explain the power source, hegemony, and bias with a certain reference to the contextual relations of society, politics and history. The investigation of text is a key exercise in the research of discourse analysis, as Van Dijk (1993) investigated the reports of newspapers to explore the importance of their position in the development of cultural bonds.

Van Dijk (2008) has presented his famous socio-cognitive modal for CDA on the bases of interconnection between discourse, society and cognition. Van Dijk's modal is an ample parameter for the analysis of newspapers in terms of cultural, political, strategic and social prejudice and the manipulation of ideologies. Van Dijk (1998) explains that his modal, "is able to explain how ideologies monitor practices of social actors in society" (p. 23). Van Dijk offers macro and micro levels in his modal of CDA. The use of verbal interaction, language and communicative strategies become under the micro level in a social order whereas dominance, inequality, power, and bias among the different groups of society are headed with the analysis of macro level. Wodak and Fairclough (1997) concluded the focal concerns of CDA in the following key points:

1. CDA deals with social issues and ideologies

2. Discourse depicts society and culture

3. Power relations are always circuitous

4. The nature of discourse is historical

5. It considers the moderate bond of text and society

6. Discourse analysis provides explanations and its nature is social

This paper targets at observing that how Pakistani media paints the same project with geostrategic and political colours through news headlines. CPEC (China-Pakistan Economic Corridor) is considered to be 'a gateway of development' for Pakistan, (Express Tribune 2017) 'a regional connectivity' for China, (The Nation 2017) 'an unrest and tension for the anti-Pakistan states' like India (Dawn News 2015) and above all 'a game changer' (BBC News, Gulf News, The Hindu, Dawn News 2015, 2017, 2016, 2016) for rest of the world. China-Pakistan Economic Corridor is a framework inked between China and Pakistan for different mutual interests and developmental concerns .It is a cooperation framework (ANI News 2017) of regional connectivity that will link China's city Kashghar with Pakistan's city of Gawader (the largest deep water sea port in the world and an economic lifeline in the region) (Bilal 
Umar 2012). CPEC will not only be beneficial for Pakistan and China but also will bring many positive impacts for Afghanistan, Iran, India,as well (Zee News 2016). China Pakistan Economic Corridor (CPEC) is mainly a journey towards economic regionalization in the sense of globalization. Its foundations are on peace, connectivity, mutual benefits, development, and win-win model for all (Masood Khalid 2016). It is a hope for the better future of the region with the message of peace, development and economic prosperity.

As CPEC has mesmerized the whole region (and world as well) and it is being discussed with different points of view and different geostrategic and political interests. When we talk about the outside world we should not go far without talking about India because India is directly or indirectly is being influenced and influencing the project (Times of India 2017). India is showing a great interest in this project. As CPEC passes through the disputed territory of Kashmir and this region is an apple of discord between India and Pakistan for decades (The Indian Express 2016). India is trying to sabotage the CPEC by all the open and secret intrigues (Express Tribune 2016). Chinese intelligence agencies also reported to the agencies and authorities of Pakistan about some suspicious activities of an Indian intelligence agency "Research and Analysis Wing" (RAW) seeking to sabotage this project Express Tribune 2015). By involving in some suspicious and secret activities RAW is trying to create unrest among the Baloch people by enticing anti-state elements and emotions of hate and disbelief for the authorities and CPEC projects (Express Tribune 2016). In March 2016 Pakistani agencies declared that they have arrested a suspected Indian spy Kulbushan Yadav who entered Pakistan via Iran especially to disrupt CPEC and destabilise peace in the province of Balochistan to sabotage the CPEC projects implementations (Express Tribune 2016). On the other hand Indian Prime Minister Nerandra Modi threatens Pakistan over CPEC.

It is a game changer for Pakistan's economic expansion, prosperity and development. It will help Pakistan to emerge as an economically strong state. This is a game changer for China as it will make easy connections for China with Gulf and European states and minimise the distance and expenses of oil trade. So there are plenty of opinions and point of views about CPEC for being this a game changer all over the globe (BBC 2015).

The stake of China in Gawader will also provide it freedom to create its influence to the Indian Ocean, which is the route of an utmost importance for the transportation of petroleum amongst the Pecific and Atlantic. The other benefit for China is that it will provide a chance to bypass the Strait of Malacca, because China imports $60 \%$ of its oil from Middle East, and $80 \%$ of this oil reaches to China via strait of Malacca, and this is a dangerous, piracy-rife maritime route through the South China, East China, and Yellow Sea (BBC 2015). Despite Melacca Dilemma challenges faced in the area of the strait of Melacca, China badly depends on the sea-routes that pass by the South China Sea, near the disputed Paracel Islands and Spartly Islands, which are the cause of dispute between China, Philippines, Vietnam, Taiwan, and The United States. The CPEC will let Chinese petroleum imports to sidestep the disputed routes and find a new artery in the west, and will minimise the chances of tension between the USA and China (BBC 2015).

CPEC is a chain of proposed and under construction projects with the investment of $\$ 46$ billion and all this investment is being projected by China (BBC 2015). The major target of this mega project is to expand and upgrade the infrastructure of Pakistan at rapid pace as well as to deepen and broaden the bilateral geostrategic, political and economic bonds of Pakistan and China. The importance of CPEC to China is reflected by its inclusion in China's $13^{\text {th }}$ five year development plan (Weindong 2015)."

The importance of Gawadar port is that, geographically it is located at the south west of the Baluchistan sharing its borders with Afghanistan and from Western border with Iran which is almost 100 kilo meters away. Uniqueness of it is that it is just 180 nautical miles (330 kilo meters) away from Strait of Hormuz which is enriched with oil that accounts for $20 \%$ of world's oil trade (total $35 \%$ oil trade is done by sea). 
More than $85 \%$ of this oil exports reaches Asian Market, India, Japan, China, and South Korea representing the largest destination. It is a highly important strategic and geographic location for International trade and it is considered that being the stakeholder at Gawadar port China may control the biggest portion of world's trade (Gawadar Gate 2016).

\section{Methodology}

It is an analytical research of media discourse that primarily studies how social power and inequality is manipulated and reproduced through text and talk in both social and political contexts. CDA of journalistic discourse tries to unveil the biased language to make the readers aware of manipulative strategies used in both printed and online news papers.

In Applied Linguistics Critical Discourse Analysis is a tool to analyse and observe the news headlines to scrutinize the hidden strategy and hidden message of the news headlines in a certain scenario about a certain phenomenon. CDA has become a very attractive and effective tool for the scrutiny of the power relations of discursive strategies in the last few decades. The agenda of CDA is to scrutinize the non transparent power bonds to expose the masked ideology inserted in it (Fairclough, 1995). CDA targets to make these correlations crystalline among the practices of discourse, societal norms and social connections that might be unclear for a layman (sheyholislami 2001).

\subsection{Sample}

The data for the current study is collected from three daily English news papers from Pakistan; The Dawn News, The Tribune, The Business Recorder. Following news headlines has been selected for the analysis under the modal of CDA by Van Dijk.

The present study aims at making a comparative study of three daily English newspapers, The "Dawn News", "The Tribune" and "The Business Recorder" about the news headlines on CPEC (ChinaPakistan Economic Corridor) to show the negotiation on the important issues like CPEC via news headlines.

\section{Industrial potential; deep sea port in Gawader would turn things around. (Tribune,March 17, 2016)}

2. India out to sabotage CPEC; Raheel. (Dawn News, April 13, 2016)

3. CPEC dream turns into reality as Gawadar Port goes operational (Business Recorder, November 18, 2016)

\subsection{Instrument}

The data will be analysed through CDA of media as the tool of research. The nature or method of the representation of analysis will be qualitative. The objective of the current study is the representation and analysis of different local English news headlines about a single issue in different ways. The researcher will use Van Dijk's approach of media text analysis to analyse these news headlines on macro and micro levels of the modal.

\section{Data Analysis and Findings}

The nature of the study is qualitative. The results show a controversial approach towards the acceptance of this mega project and apprehensions of the stake holders and political figures.

\subsection{Background of the Text One}

- Online source

- Online Daily print

- Text: CPEC Potential: Deep Sea port would turn things around (March 17, 2016)

- Ideology: Two Nation Theory 
- Participant: Pakistan's leaders, people, neighbours, supporters.

- Macro strategy: The Editor of Express Tribune shows uncertainty that CPEC "would" change the scenario if it goes successfully operational.

- Micro strategy: Declarative statement, to impart introduction, he is uncertain about the CPEC projects implementation.

- Report Length: It is a brief report to keep the interest intact.

- No of sentences: There are 22 sentences.

- No of points: discussed three main points, Pakistan's internal and external challenges, prospects and solutions.

- Addressee one: Pakistan's leaders, people, neighbours, supporters

- Addressee two: India, UNO, China, USSR Conclusion: The writer is building a background of the project. There is an initial air of uncertainty.

\subsection{Background of Text Two}

\section{Dawn News}

- Online source

- Online daily print

- Raheel Sharif's statement

- Text: India out to Sabotage CPEC; Raheel (April 23, 2016)

- Ideology: Two nation theory

- Participants: Pakistan and the outer world especially India.

- Addressee one: Pakistan's leaders, people, neighbours, supporters

- Addressee two: India, UNO, China, USSR

- Macro strategy: Editor of Dawn news is to keep the world alarmed about any terror activity or negative activity against CPEC

- Micro strategy: declarative statement, he is very clear that India has hidden agenda

- Report length:short

- No of sentences: 10

- No of points: only two

- Conclusion: Direct message of COAS of Pakistan to India about defensive strategies of Pakistan Army.

\subsection{Background of text three}

- Business Recorder

- Online source

- Online daily print

- Text: CPEC dream turns into reality as Gawadar port goes operational (November 18, 2016)

- Ideology: Two nation theory

- Participants; Government of China and Pakistan and outside world.

- Addressee one; Pakistan's leaders, people, neighbours, supporters

- Addressee two; India, UNO, China, USSR

- Macro strategy: editor of Business Recorder declares the successful start of CPEC projects and function of Gawadar port

- Micro strategy: declarative statement, to import the information.

- Report length: Medium

- No of sentences: $20-22$

- No of points: only one

- Conclusion: direct way of addressing the world at large. 


\section{Conclusion}

The study shows that these are different points of view of the editors who present things to their readers. The selected texts show a gradual development of the CPEC progress in the region. The text 1 provided a background with uncertainty. After reassurance from the existing Army Chief, situation changed and the outer forces were warned about any malicious designs. Text 3 provided an optimistic note at the completion of the project. From the analysis of all three texts it has been explored that how media manipulates the facts to create the impact of a certain phenomenon. Present study reassures that media discourse is a tool to unveil the role of media in designing the mindset of masses. The present century is the media oriented century and media plays a dominant role in designing the events according to the situation.

\section{References}

Alejandra Roman \& Administration (June 02, 2015). "Strait of Hormuz". The Encyclopaedia of Earth. Ani news China (25 ${ }^{\text {th }}$ Marc 2017) http://www.aninews.in/newsdetail-MTY/MzA1Nzk5/cpec-is-039cooperation-framework-039-to- pursue-long-term-development-china.html

BBC News (April 22, 2015). Is China-Pakistan Silk Road a Game Changer? http://www.bbc.com/news/world-asia-32400091

Dawn.com.pk (28th September 2016) https://www.dawn.com/news/1286475/russian-researcher-says-cpecgame-changer-for-the-region

Dawn News (3rd Jun 2015) https://www.dawn.com/news/1185779

Gulfnews.com (28th February 2017) http://gulfnews.com/news/asia/pakistan/cpec-game-changer-forregion-nawaz-sharif-1.1986146

Muhammad Bilal Umer (17th February 2012) World's Largest Sea Port Gawadar. University of Technology Australia. https://travellerem.com/2012/02/17/worlds-largestdeep-sea-port-gwadar/

Muhammad Nawaz Khan (15th January 2016) CPEC-A Game Changer. http://www.ipripak.org/cpec-agame-changer/

Norman Fairclough (1995). Critical Discourse Analysis: The Critical Study of Language. London and New York: Longman.

Norman Fairclough and Wodak Ruth (1997). Critical Discourse Analysis. In T.A. Van Dijk, ed., Discourse as Social Interaction: $\quad$ Discourse Studies: A Multidisciplinary Introduction, vol. 2. Thousand Oaks.

Pakistantoday.com.pk (23rd November 2015) https://www.pakistantoday.com.pk/2015/11/23/cpec-madepart-of-chinas-13th-5-year- development-plan-weindog

The Express Tribune (17th March 2016) httpst://ribune.com.pk/story/1067204/industrial-potential-deepsea-port-in-gwadar-would-turn-things-around/

The Nation (12th July 2016) http://nation.com.pk/columns/12-Jul-2016/cpec-the-game-changer

The Nation (6th March 2017) http://www.cpecinfo.com/cpec-news-detail?id=MTU5NQ

The Express Tribune (10th April 2017) https://tribune.com.pk/story/1379267/anticipating-developmentcpec-gateway-pakistans- prosperity-says-iqbal/

The Express Tribune (14th April 2016) https://tribune.com.pk/story/1084291/in-camera-briefing-rawset-up-cell-to-sabotage-cpec/

The Express Tribune (22nd May 2015) https://tribune.com.pk/story/890650/raw-at-frontline-to-sabotageeconomic-corridor-china-warns- pakistan/

The Indian Express (4th September 2016) http://indianexpress.com/article/india/india-news-india/primeminister-narendra-modi-raises- indias-concern-over-cpec-which-runs-through-pok-3013260/

The Express Tribune (25th March 2016) https://tribune.com.pk/story/1072455/terror-purge-forces-nabindian-spy-in-balochistan/

http://www.gwadargate.com/

Times of India (7th March 2017) http://timesofindia.indiatimes.com/world/china/india-should-beflexible-and-pragmatic-about-pok-says- china-in-a-pitch-for-

cpec/articleshow/57511262.cms 
The Handbook of Discourse Analysis, 2nd Ed. Edit. By Deborah Tenon. (2015). John Wiley and Sons. Van Dijk (1988). News Analysis: Case Studies of International News in the Press. Hillsdale, NJ: Lawrence Erlbaum.

Van Dijk (1993). Elite Discourse and Racism. Newbury Park, CA: Sage.

Van Dijk (1998). Ideology: A Multidisciplinary Approach. London: Sage.

Van Dijk (2008). Discourse and Context: A Socio-Cognitive Approach. Cambridge and New York: Cambridge University Press.

Weindong (November 23, 2015). CPEC Made Part of China's 13th 5-year Development Plan.

Yulin Magazine China (11th March 2016) China-Pakistan-info http://www.nihao-salam.com/newsdetail.php?id=ODM1OA

Zee News India (30th December 2016) http://zeenews.india.com/india/india-afghanistan-irans-entry-intocpec-project-will-benefit-all-says-china 1962996.htmlomic Forum 


\section{Appendix I}

Industrial potential: Deep sea port in Gawadar would turn things around (The Express Tribune)

Karachi: The Gawadar Port holds immense potential for industrial investment in view of the opportunities offered through the establishment of a deep sea port, which is capable of accommodating large vessels of up to 70,000 Deadweight Tonnage (DWT), said China Overseas Port Holding Company (COPHC) Chairman Zhang Baozhong.

During his visit to the Karachi Chamber of Commerce and Industry (KCCI), he informed the gathering that the Makran Coastal Highway (N-20) had been completed, which had substantially reduced distance between Karachi and Gawadar.

"Upon completion, the Gawadar Port would be a gateway for business as it would cater to all types of international commercial activities," he added.

"The COPHC was granted 40 years concession in 2013 to manage and operate the Gawadar Port and Gawadar Free Zone and it had been the objective of the COPHC to develop the region's most strategically well-located port with state-of-the-art facilities," remarked Baozhong.

"It has been mostly the local workface and contractors that have been engaged in carrying out the development work at the port and they are doing an excellent job."

Baozhong added that largest free zone, covering an area of 968,000 sq meters, for warehousing, manufacturing, international purchasing transit and distribution trans-shipment, commodity display and supporting services had also been established. "The free zone is exempted from federal, provincial and local taxes and would make Gawadar an attractive port for marine trade."

"COPHC also intends organising an international fair every year in Gawadar, in collaboration with the Governments of Pakistan and China to highlight the potential of this important port which would become the distribution centre for the Middle East market. "The Gwadar port will prove to be a gamechanger for employment for local inhabitants," said the Business Group Vice Chairman and KCCI former president Anjum Nisar.

"The COPHC also plans to establish the deepest berth of 20 metres; this means that some of the largest vessels would be berthed at the port, bringing in more prosperity not only for Pakistan, but for the entire region," added Nisar.

Published in The Express Tribune, March 17 $7^{\text {th }}, 2016$.

\section{Appendix II.}

India out to sabotage CPEC: Raheel (Dawn News)

GAWADAR: Chief of Army staff General Raheel Shareef has said that hostile intelligence agencies, especially the Indian spy agency, Research and Analysis Wing (RAW), are trying to destabilise Pakistan after many countries of the world have appreciated the true potential of the China-Pakistan Economic Corridor (CPEC).

He was addressing a seminar held in connection with the CPEC in the port town of Gawadar on Tuesday.

The COAS said: "Now, zooming out to the global and regional level, we have seen a wide appreciation by many world powers of the true potential of the CPEC project as a catalyst of economic transformation of the entire region."

He added, however, that at the same time, the CPEC had also raised the eyebrows of those competing for influence in the region.

He said that in this context he must highlight that India has openly challenged this development initiative. "We all know that hostile intelligence agencies are averse to this grand project. Here, I would like to make a special reference to Indian intelligence agency, RAW, which is blatantly involved in attempts aimed at destabilising Pakistan," General Raheel said. He stressed, however, that they would 
not allow anyone to create impediments and disorder in any part of the country. He added that it was important for everyone to leave behind confrontations and focus on cooperation.

He said that since the onset of CPEC, Balochistan has seen unprecedented development of communication infrastructure. "We mobilised army engineers for construction and army and Frontier Corps units for security $f$ the projects," he said.

Referring to Gawadar, he said that with the port city as the pivot, the dividends of CPEC would be reaped not just by Baluchistan but shall spread across the entire rim of the Indian Ocean.

Published in Dawn, April 13 ${ }^{\text {th }}, 2016$

\section{Appendix III.}

\section{CPEC dream turns into reality as Gawadar Port goes operational (Business Recorder)}

ISLAMABAD: THE CHINA PAKISTAN ECONOMIC CORRIDOR (CPEC) had become a reality with the departure of the first trade cargo from Gwadar Port to international destination, Khaleej Times reported.

According to the newspaper, Prime Minister Muhammad Nawaz Sharif said "The arrival of the first trade convoy at Gawadar Port 'a watershed event', as the China Pakistan Economic Corridor(CPEC) project had materialized, marking the dawn of immense trade and commerce opportunities for the whole region".

Addressing a ceremony marking the departure of the first major trade cargo from Gawadar Port on last Sunday, the Prime Minister said Pakistan was a proud partner of China and added that his government would leave no stone unturned to complete all development projects under the umbrella of CPEC on time.

He said the CPEC manifested the desire of the leadership of two countries for shared prosperity through a broader and solid cooperation, the paper added.

The Prime Minister lauded the Chinese President $\mathrm{Xi}$ for his vision of regional prosperity which coincided with Pakistan's vision of development, adding that the President Xi's vision of shared prosperity through greater connectivity was need of the hour in the conflict-ridden and increasingly polarized world.

The CPEC was the fusion of Chinese President's concept of one-belt one-road project which aims to integrate trade and commerce activities of various regional countries through enhanced connectivity, thus transforming Pakistan into a major hub of trade and commerce, he added.

The prime minister reiterated that the CPEC was going to be a reality and would open a world of opportunities for the countries and the region.

Terming the Gawadar Port a 'jewel in the CPEC crown', he expressed the confidence that due to its geostrategic location, it would olay a pivotal role in future trade and cargo activities.

He said the vision of exclusive and sustained development must reach to those who had been mired in poverty and backwardness and in that regard the CPEC would provide benefits to the all the underdeveloped areas of the country, including Baluchistan, KPK, Fata, AJK and Gilgit-Baltistan.

He said that no area of the country would be deprived of the fruits of prosperity from various CPEC development projects.

He expressed the hope that with the execution of various development projects, bilateral relations between China and Pakistan would reach further heights.

"CPEC is for entire Pakistan and no region or province will be left out of it", Sharif said.

Khaleej Times further reported that the newly-constructed roads in Baluchistan have opened up new areas that were inaccessible and deprived of development... these developments have brought peace to a volatile region. The prime minister said "The newly-constructed roads in Baluchistan have opened up new areas that were inaccessible and deprived of development... and have brought peace to a volatile region."

The government of Baluchistan and the army have been successful in making the local population a stakeholder in development, the paper added.

November $18^{\text {th }}, 2016$. 